\title{
Path Analysis on the Development of Scientific Researches in Private Colleges
}

\author{
Liu Qiong \\ Medical School Xi'an Peihua University \\ Xi'an 710000 , China \\ e-mail: liuqiongsmile@126.com \\ Liu Libin * \\ Medical School Xi'an Peihua University \\ Xi'an 710000 , China \\ e-mail: liulibin@peihua.com
}

\author{
Liu Lu \\ School of Life Sciences Tsinghua University \\ Beijing 100084, China \\ e-mail: liuluxn@163.com
}

\author{
Ma Feng \\ School of Civil Engineering BeiJing JiaoTong University \\ Beijing 100044, China \\ e-mail: mafengsh@163.com
}

\begin{abstract}
In 2015, the government put forward explicitly the target of the world-first class university and the word-first class discipline. For a period, double-first class construction will be the key point of our country's higher education reform and development. Private higher education is an important part of our country's higher education. Constructing university-enterprise cooperation of scientific research platform, introducing academic leaders, compacting direction of research, and strengthening the performance management of scientific research, that will promote the development of scientific research in private colleges, and promote double-first class construction of private colleges, so as to promote the whole development of double-first class construction in all of colleges and universities.
\end{abstract}

\section{Keywords-Double-first Class Construction; Scientific Researches; Private Colleges; Path \\ I. PRIVATE COLLEGES ARE AN IMPORTANT PART OF CHINA'S DOUBLE -FIRST CLASS CONSTRUCTION}

October 24, 2015, the state council issued the overall plan to promote the construction of the world-class university and the word-first class discipline. It proposed specifically: by 2020, a number of universities and a number of disciplines will achieve world-first class level, and several disciplines will be to the world-first class disciplines. By 2030, more and more universities and disciplines will achieve world-first class level, and several universities will be the leads of the world-first class universities, and a group of disciplines will be the lead of the world-first class disciplines, so as to the overall strength of higher education will have increased significantly. By the middle of this century, the quantity and strength of word-first class universities and disciplines will have entered the forefront of the world, and our country will have completed the great power of education basically. The ultimate goal of double first class construction is to realize the transformation of China from the big education country to the great power of education, cultivate high-quality talents and realize the great rejuvenation of the Chinese nation. Therefore, it is of great importance to promote the whole level of private colleges.

\section{A. Private colleges are an important part of China's double - first class construction}

Since the reform and opening up, private colleges in our country have been developed rapidly, and the quantity and scale of private colleges have expanded rapidly. In December 2002, "Law for Promotion of Private Education" has made an express provision that the private higher education is an integral part of Chinese socialist education. From 2012 to 2016, according to the statistics bulletin of the national education career, five years, the number of private colleges in our country increased from 707 to 742 (including 266 independent college), accounting for $29 \%$ of the number of common colleges and universities around the country(Figure 1); The enrolment of private colleges increased from 533.17 million to 633.98 million, accounting for $24 \%$ of the total enrolment of common colleges and universities around the country(Figure2). Thus it can be seen that the Double - first class Construction in China is inseparable from the development of education of private colleges, and the improvement of the overall quality of education is inseparable from the improvement of private colleges education quality.

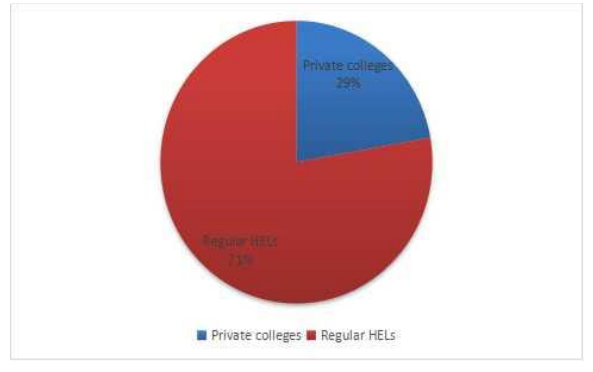

Figure 1. The number of private colleges. 


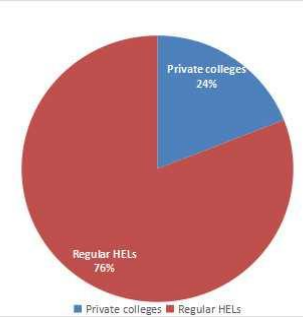

Figure 2. The enrolment of private colleges.

\section{B. The existing development level of private colleges has hindered the development of double-first class construction}

Even though the existing private colleges occupy nearly a third of the total position in our country's higher education, but comparing with the public colleges and universities, the quality of private colleges is uneven, and the overall social reputation is low, that is in the disadvantage of higher education. From the perspective of the school type of foreign higher education, there is little to choose between private colleges and public colleges. E.g., nearly 2 years times, six of the world's top ten universities is private schools in the Thames high education, which is one of the most famous global universities ranking. That's California Institute of Technology, Stanford University, Massachusetts Institute of Technology, Harvard University, Princeton University and The University of Chicago, accounting for $60 \%$. Of course, the development of these foreign private colleges and universities has its historic roots, and its development has a long history, even before the majority of public universities in the country. It is based on this that the country puts forward double-first class construction. If the quality of private higher education is not to be ascended, double-first class construction is only focused on public colleges and universities, which will have formed a high quality education resources monopoly, and lead to education unfair phenomena, and it will be different from the ultimate goal of double-first class construction. So, just under the background of double-first class construction, the existing development of private colleges need to ascend to promote the whole education quality.

\section{STRENGTHENING SCIENTIFIC RESEARCH CONSTRUCTION IS THE KEY TO PROMOTE THE DEVELOPMENT OF PRIVATE COLLEGES}

According to the research of the existing achievements, it is highly positive correlation between academic level and university development level, and subject level affects the international status and academic reputation of the university greatly. As a result, the world first-class discipline construction is the foundation of the world first-class university construction, and the construction of the world first-class universities must start with the first class discipline as a starting point and focus. So what are the world first-class disciplines, and what are the criteria for world first-class disciplines? According to Academic Ranking of World
Universities, i. e. one of the most famous global universities ranking, the measure of world first-class discipline ranking includes five aspects mainly. Respectively, they are the number of alumni won the Nobel Prize and the fields medal (Alumni), the number of teachers awarded the Nobel Prize and the fields medal (Award), the number of teachers with the highest citation rate in every subject area $(\mathrm{HiCi})$, the number of papers published in the journal Nature and Science(N\&LS), and the number of papers from SCIE and SSCI (SCI). All of them are very important achievements in the construction of scientific research. At the same time, in combination with current private colleges ranking in China, the number of private colleges that have achieved a lot of research results are at the top of the list, and vice versa.

TABLE I. THE RANKING OF CHINA'S PRIVATE UNIVERSITY IN 2017 BY WU SHULIAN

\begin{tabular}{|c|c|c|}
\hline Ranking & Total Score & $\begin{array}{c}\text { Scientific } \\
\text { Research Score }\end{array}$ \\
\hline $\begin{array}{c}\text { Zhejiang } \\
\text { Shuren } \\
\text { University }\end{array}$ & 4.37 & 2.43 \\
\hline $\begin{array}{c}\text { Huanghe S\&T } \\
\text { University }\end{array}$ & 4.35 & 2.16 \\
\hline $\begin{array}{c}\text { Changsha } \\
\text { Medical } \\
\text { University }\end{array}$ & 2.98 & 0.17 \\
\hline $\begin{array}{c}\text { Jilin HuaQiao } \\
\text { University }\end{array}$ & 2.40 & 0.07 \\
\hline $\begin{array}{c}\text { Xijing } \\
\text { University }\end{array}$ & 2.38 & 0.64 \\
\hline $\begin{array}{c}\text { Hunan } \\
\text { International } \\
\text { Economics } \\
\text { University }\end{array}$ & 2.36 & 0.81 \\
\hline $\begin{array}{c}\text { Dalian Neusoft } \\
\text { University of } \\
\text { Information }\end{array}$ & 2.35 & 0.32 \\
\hline $\begin{array}{c}\text { Sanya } \\
\text { University }\end{array}$ & 2.15 & 0.32 \\
\hline $\begin{array}{c}\text { Beijing City } \\
\text { University }\end{array}$ & 2.15 & 0.27 \\
\hline $\begin{array}{c}\text { Sanjiang } \\
\text { University }\end{array}$ & 2.13 & \\
\hline
\end{tabular}

What's more, the research foundation of private universities is weak generally, and discipline construction lacks sustained motivation. Strengthening the construction of scientific research can grasp the latest dynamic of subject development, and then it can be applied to teaching, which will develop the quality of teaching, and cultivate high quality students, so as to promote the development of private colleges comprehensively. Therefore, strengthening the construction of scientific research is the key to promote the double-first class construction of private colleges. 
III. PATH ANALYSIS ON SCIENTIFIC RESEARCH CONSTRUCTION IN PRIVATE UNIVERSITIES UNDER THE BACKGROUND OF DOUBLE-FIRST CLASS CONSTRUCTION

Due to the single source of school funds in private colleges, private colleges don't pay enough attention to the scientific research. Funds of construction of scientific research is not high, supporting facilities is insufficient, and it is a drop in the ocean that only relies on the government of all kinds of longitudinal project application for scientific research. This limits the development of the construction of scientific research greatly. At the same time, the whole atmosphere of scientific research in private colleges is weak, and it is generally not enough emphasis on scientific research, so everybody does not care about scientific research, everyone doesn't do research, and the performance appraisal of teachers' scientific research ability is relatively not enough. Thus in this prevailing climate, it's hard for the sustainable development of scientific research. In addition, because of big personnel fluidity in private colleges, it lacks of historical heritage of scientific research and scientific researches project only depend on some staff, which limits the development of the construction of scientific research deeply. Therefore, the key point to develop scientific research in private colleges is to broaden funds source channels of scientific research, strengthen the introduction of talents, compact research development direction, and enhance performance management, so as to promote the sustainable development of scientific research in private colleges.

A. Promoting the construction and operation of university-enterprise collaborative research platform, and solving the financial difficulties in the development of scientific research in private colleges

Scientific research platform is a system to gather talented, develop high level scientific researches, and output high level researches. Scientific research platform of narrow concept refers to a work platform that the scientific research personnel work for specific research in specific subject areas, e. g. , all kinds of key laboratory can be classified as research platform. As early as the mid-20th century, the university-enterprise collaborative research platform was carried out at abroad. For private colleges, it will help decreasing the cost of scientific research in colleges, to solve the key source of funding problems in the development of scientific research construction. Meanwhile, relying on the social demand for scientific research, university-enterprise cooperation will help to improve the quality of scientific research, and promote the conversion rate in scientific research achievements. Different from cooperation platform between public colleges and enterprise, the main way of collaboration between private colleges and enterprises in the area of scientific research is: the open platform, enterprise investment, and talent output of colleges, to optimize resources and share achievement together.

First of all, scientific research atmosphere is relatively weak in private colleges.In addition to the teaching activity, all kinds of laboratory are underutilized in scientific research. Private colleges can open laboratory for the society, providing free scientific research platform, and enterprise use this platform to solve their problems such as product research and development, production process improvement and so on. Secondly, private colleges' teachers participate in the scientific research project of the enterprise, providing intellectual support for the enterprise, and the enterprise bear the funds needed in the process of scientific research project. Finally, through a formal agreement to standardize the whole process of cooperation, the results of scientific research project are belong to private colleges, and enterprises are free of charge to use them, which will realize win-win cooperation between private colleges and enterprises. At the same time, the scientific research relying on the enterprise actual development needs are eventually applied to social production, which improves the ability to serve the society greatly, and this is also efficient path to promote the social scientific research achievements conversion to solve the problem of low scientific conversion rate in the country.

\section{B. Paying special attention to the statistics and analysis of scientific research data and compacting research development direction}

Due to large mobility of personnel private colleges, there is often a fault phenomenon of scientific research development. The loss of core staff causes the waste of all kinds of resources such as instruments, equipment and so on. Private colleges can make full use of all kinds of scientific research statistics, to establish scientific research statistics database, and then use big data analysis technology to classify existing scientific research direction. At the same time, combining with social development needs and subject dynamics, private colleges can confirm of scientific research. And in the key development direction, private colleges give key support in talent introduction, equipment purchase, etc, to realize that the talents follow with the direction of scientific research development, which will avoid the phenomenon of termination of scientific research projects, so as to realize the continuity of scientific research development, and the accumulation of scientific research.

\section{Introducing academic leaders, implementing PI}

The other main reason for the lagging development of research in private universities is the lack of the talent team. It can alleviate this problem to introduce academic leaders and implement PI. As an abbreviation of Principle Investigator, PI is an organizational form of modern science and technology activities. It is based on a certain academic leader and is appropriately equipped with resources such as manpower, equipment and funds. In this organizational unit, the academic leader is in a sovereign position, having the responsibility to maintain the existence and development of the unit, as well as the full power. Because of its weak scientific research foundation, private colleges can introduce academic leaders according to the need of discipline construction development, so as to gather the existing 
scientific research resources, and form the team of scientific research. And then private colleges can establish natural and social research base by the lead of academic leader, and each department of secondary research team can be into the base. It can be beneficial to realize the professional people do professional thing, and enhance the management level of scientific research, that will achieve fast breakthrough of research development in private colleges.

\section{Strengthening the performance management and realizing the sustainable development of scientific research construction}

The development of scientific research construction is not accomplished overnight, and it needs sustainable effort. Under the existing resources, the scientific research construction of private colleges must strengthen the performance management, and the limited resources should be used in the real place and realize the optimal development of scientific research construction.

In order to improve the performance management of scientific research construction, it can start from three aspects. First, improving the scientific research performance evaluation of teachers. On the basis of the analysis of research data, combining with its own development requirements, private colleges increase scientific research performance appraisal on the index of evaluation of teachers, and improve scientific research reward policies at the same time to encourage teachers to focus on scientific research actively, and participate in it, so as to promote the development of the whole scientific research. Second, strengthening the performance management of scientific research process. Since of its weak scientific research foundation in the most of private colleges, private colleges lack in the management of scientific research. Therefore it need to establish a file of scientific research project and a dynamic regulatory mechanism. From the beginning of the various types of scientific research projects, checking it without day urges the completion of scientific research project and improves the quality of scientific research project. Finally, strengthening the performance appraisal of the value of each research project. When the scientific research have certain development, and the number of scientific research achievements accumulate to a certain extent in private colleges, it need to pay more attention to the quality of scientific research. It should calculate the input-output ratio of scientific research project and do performance appraisal. It's in the form of bidding to set up scientific research project or distribute funds, i.e. academic teams leading by academic leaders propose research programs, afterwards scientific research management make decisions on the base of comprehensive evaluation value of each research project. In this way,it can achieve the optimal allocation of scientific research resources, at the same time it can strengthen the assessment of academic leaders and their teams to introduce competition mechanism to promote the sustainable development of private colleges scientific research.

\section{CONCLUSION}

Double-first class construction is the focus of the development of higher education in China. As an important part of China's higher education, the ultimate realization of double-first class construction cannot be achieved without the improvement of the overall quality of private colleges. Strengthening scientific research construction is the key to promote the development of private colleges. This paper expounds the main ways to promote the development of scientific research in private colleges from three aspects. Firstly, it should promote the construction of universityenterprise collaborative research platform to solve the financing dilemma of the scientific research. Secondly, paying attention to the statistics and analysis of scientific research data and compacting the development direction of scientific research; Thirdly, introducing academic leaders and implementing PI system; Finally, strengthening the performance management, to realize the sustainable development of scientific research in private colleges.

\section{ACKNOWLEDGMENT}

Thank you very much for providing us with valuable exchange opportunities, and thanks to my family, especially my precious son, for my support, which is the source of my strength.

R. B. G. thanks.

\section{REFERENCES}

[1] Guangli Zhou, Jianxin W, "What is a world class discipline," China Higher Education Research. BeiJing, vol. 3, pp. 65-73, May 2017.

[2] Guangli Zhou. "The academic breakthrough in "double - first class" construction--on the construction of university subject and curriculum integration," Educational Research. BeiJing, vol5, pp. 72-76, May 2016.

[3] Shenghui Zhu,"The development orientation of private undergraduate colleges and universities in the background of "double-first class"Journal of Zhejiang Shuren University. HangZhou, Vol. 17, pp. 20-23, May 2017. 